\title{
Dictynna
}

Dictynna

Revue de poétique latine

15 | 2018

Varia

\section{Plautus, Menaechmi: Twin Helping Twin}

\section{Stavros Frangoulidis}

\section{(2) OpenEdition}

\section{Journals}

Electronic version

URL: http://journals.openedition.org/dictynna/1688

DOI: 10.4000/dictynna.1688

ISSN: 1765-3142

\section{Electronic reference}

Stavros Frangoulidis, «Plautus, Menaechmi: Twin Helping Twin », Dictynna [Online], 15 | 2018, Online since 20 December 2018, connection on 10 December 2020. URL : http://journals.openedition.org/ dictynna/1688; DOI : https://doi.org/10.4000/dictynna.1688

This text was automatically generated on 10 December 2020 .

\section{(c) (i) (9)}

Les contenus des la revue Dictynna sont mis à disposition selon les termes de la Licence Creative Commons Attribution - Pas d'Utilisation Commerciale - Pas de Modification 4.0 International. 


\title{
Plautus, Menaechmi: Twin Helping Twin
}

\author{
Stavros Frangoulidis
}

\section{AUTHOR'S NOTE}

The Latin text and English translations of Plautus' Menaechmi are quoted from the latest Loeb edition by De Melo, 2011. Here I wish to express my gratitude to David Konstan for his constructive criticism on an earlier version of this paper; to Ben Petre, Yannis Tzifopoulos and Niki Ikonomaki for helpful discussions; to the anonymous readers for their thought provoking comments and suggestions; and, last but not least, to the Editors of Dictynna, Jacqueline Fabre-Serris and Florence Klein; I also want to thank especially the former for her warm encouragement and support. Any errors remaining are my own.

1 Plautus' Menaechmi revolves around the young Menaechmus I, abducted as a child from Tarentum and now leading a seemingly normal life in Epidmamnus. He is married to a matrona dotata and enjoys a life of almost daily feasting with a courtesan (Erotium) and a parasite (Peniculus). However, Menaechmus I is henpecked by his domineering wife and is systematically exploited by Peniculus, his clients and the greedy meretrix. ${ }^{1}$ Almost simultaneously, conditions ripen for the termination of this life, with Menaechmus I's alienation from his familial and social milieu, and his eventual removal from the polis, thus offering a truly happy ending typical of Plautine comedy. This is facilitated by the arrival of Menaechus II, his identical twin, who has set out from Syracuse in search of him.

2 The play centres on how Menaechmus II comes to be taken for his brother in two incidents, the second of which in many respects repeats the first. In acting out his new found role, Menaechmus II exposes the true character of the Epidamnians and eventually releases his twin from their clutches. In the first instance Menaechmus II unwittingly usurps his brother's role as composer of an inset comedy and enjoys a feast 
in the company of Erotium; the situation thus created helps distance Menaechmus I from his closest company. In the second instance, Menaechmus II unawares again impersonates his brother, who has supposedly been driven insane, and so effects the further separation of Menaechmus I from the polis: the latter's father-in-law resorts to a doctor, who diagnoses the wrong twin as being out of his mind and orders his forced removal to a mental clinic. This marks the culmination of a process whereby Menaechmus I, who has never truly integrated in Epidamnus, is actively cast out of the city. At the same time, Menaechmus II's search for his twin, which is presented as a costly, futile undertaking upon his arrival in town, bears fruit through the evolution of meta-plays.

Scholars usually treat the meta-dramatic endeavors of Menaechmus II of Syracuse on two separate occasions as independent performances; ${ }^{2}$ however, their interdependence on the meta-dramatic initiatives of his Epidamnian sibling have largely escaped examination, as has their function as a tool for his gradual withdrawal from town, in compliance with the overall fabric of a play focusing on duality. ${ }^{3}$ In this interdependence of meta-poetic initiatives it becomes clear that twin helps twin throughout the action, albeit unwittingly.

4 The aim of this paper is twofold: to suggest (1) that Menaechmus II's largely unintentional yet repeated assumption of an alternative identity functions as a vehicle for his kidnapped brother's gradual separation from the society that has been exploiting him; and (2) that this gradual withdrawal occurs throughout the play, rather than just at the end, after the recognitio.

\section{Setting the objectives in context}

Doubling and mirroring of characters is, of course, a default Plautine technique drawing on the earlier New Comedy tradition. In Miles Gloriosus, for example, the courtesan Philocomasium plays her fictional twin sister, Dicea, as part of the slave's trickery. Likewise, in Casina a similar pattern is developed as the two slaves, Olympio and Chalinus, function as doubles of each other. In Pseudolus too, the sycophant Simia playing out the role of Harpax, namely of the slave belonging to the Macedonian solider whom the mereterix Phoenicium was promised to, may be read as the double of Pseudolus, the Plautine smart slave par excellence, who employs Simia in order to deceive Simo, the father of the adulescens Callidorus, who is in love with the meretrix Harpax as well as the Leno Ballio. Last but not least, as part of mythological burlesque, doubling also takes on an organic dramatic role in a Plautus' Amphitruo, where through divine mechanism Jupiter functions as a double of Amphitruo with the concomitant character mirroring of Mercury as Amphitruo's slave Sosia, leading as it does to the comic deception of Alcumena. In the case examined, the paper aims to place the comic mechanism within the dramatic context of Plautus' Menaechmi with a view to establishing the ways this Plautine device propels the plot, delineates characters and offers multiple meta-dramatic opportunities.

\section{Menaechmus I as poeta comicus}

6 Menaechmus I lives a life of seeming normalcy in Epidamnus. Despite his obscure origins he has contracted a successful marriage to a matrona dotata, has a number of 
clients and is enamored with a courtesan. ${ }^{4}$ However, the play's opening act offers an instant illustration of the way he is nagged by his domineering wife and exploited by his associates.

On entering, the parasite Peniculus announces his intention to take to his patron for yet another evening of irresponsible excess (96-9); ${ }^{5}$ but this proposal also reveals the costly way Menaechmus I is accustomed to buying the company of his client. The parasite further offers the dramatic motivation for latching onto his patron, as one who sets up extraordinarily lavish entertainments. Peniculus likens these meals to the holiday banquets held during the festival of Ceres, the ludi Cereales (101), which offers the plebeians the opportunity for rare feasting. ${ }^{6}$

From the moment he first appears on stage, the twin from Epidamnus takes on the functions of a poet, engaging in the 'composition' of one such a comic feast. He rebukes his wife for failing to be subservient to his wishes and for asking where he is going. ${ }^{7} \mathrm{He}$ further threatens to divorce her if she continues to spy on him, given the fact that he is fulfilling his part in their marriage contract by offering her whatever she needs $\left(120-1^{a}\right)$. While portraying himself as victim of his wife's excessive vigilance, he also treats her as sponsor of his revelries. This emerges from the fact that his tirade is part of staged trickery to steal her expensive gown, which he is wearing under his cloak. ${ }^{8} \mathrm{He}$ is to offer it to his mistress Erotium to buy her favors when he takes her to dinner (124): hodie ducam scortum ad cenam atque aliquo condicam foras ('I'ill take a prostitute to dinner today and engage myself somewhere outside'). The stolen garment thus becomes a prerequisite for arranging the meal, helping to define Menaechmus I's revelry as an inset play. That the husband engages in play-acting is also seen immediately after his wife's exit, when he seeks congratulations from adulterous husbands in the audience, proudly displaying the gown and recasting it as a trophy won in 'battle'. ${ }^{9}$ What is more, it turns out that the local twin is in the habit of purloining his wife's valuables to buy the favors of his meretrix, thus indicating that he is also 'enslaved' to the latter.

Peniculus overhears his patron planning to dine alone with the courtesan, and views it as a deliberate snub. He accosts Menaechmus I, determined to extract an invitation to the feast (135). In return his patron seeks praise for his latest theft; but the parasite is unwilling to share in the elation, unless he is told where the banquet will take place (150-1). Under pressure from Peniculus, Menaechmus I modifies his initial plan to include him in the entertainment at Erotium's house (152): clam uxorem est ubi pulcre habeamus, hunc comburamus diem ('There's a place where we can have a good time behind my wife's back and where we can burn this day to cinders').

10 The new plan moves a step closer to implementation when the two men encounter the meretrix outside her house. In every respect the conversation which Menaechmus I initiates with Erotium inverts his earlier dispute on leaving home: unlike the hatred expressed towards his wife, he declares his love for the meretrix (180-1); and unlike the overweening spouse who scolds her husband at every turn, the meretrix receives her lover in the most effusive terms (182), due to the expensive gifts he has brought her.

11 The subsequent action involves the staging of the comic feast. The lover comically presents the gift to his mistress as if it were a votive offering to the goddess for assistance received, and in return asks her to have her cook prepare a feast beyond the ordinary (208-13). ${ }^{10}$ The lover thus effectively renders both the meretrix and the cook actors in his meta-play. 
Beyond offering the plebeians the opportunity to enjoy rare feasting, the ludi Cereales provided the context for the staging of comic dramas. ${ }^{11}$ By skillfully combining playacting and rare feasting, Menaechmus I's initiative could render the earlier allusion to the feasts of Ceres meaningful, given the fact that his inset play is staged on a religious context within Roman dramatic festivities. Once he has issued his stage directions the local twin exits to the forum together with the parasite.

\section{Menaechmus II's arrival}

13 The countermovement marking the end of Menaechmus I's illusory happiness begins with the arrival in Epidamnus of Menaechmus II, with his slave Messenio in tow. The arrival of new characters on the scene will lead to the gradual alienation of the Epidamnian from his familial and social surroundings and eventually to the discovery of his true identity. The pair from Syracuse have spent the last six years searching for the long lost brother. The slave seems to function as an obstacle to the materialization of the comedy's end, as he points out that their dwindling finances will not permit them to continue the search for much longer. Yet Menaechmus II remains adamant that he will never abandon the quest for as long as he lives. This resolve can be understood as moving the plot to its happy end, and is possibly motivated by an awareness of the fate suffered by kidnapped children sold into slavery (242-6). ${ }^{12}$

\section{Menaechmus II's first inset comedy}

The encounter between the cook and Menaechmus II is marked by the tension between the latter's presumed identity as inset poet and his actual status as a stranger; for as long as this opposition remains unresolved, the merrymaking is withheld. Cylindrus states his surprise at seeing the inset poet arriving early for the banquet, and seeks to be informed of the whereabouts of his parasite, but Menaechmus II accuses the cook of being insane for annoying a stranger, namely someone who is not directly related to the world of the inset play (293): homini ignoto. As argued by Ketterer, Menaechmus II's mission would have ended upon his arrival in town, had not Messenio characterized the majority of its inhabitants as deceitful, thus preventing him from realizing that here as in subsequent incidents, he is being taken for his identical twin. ${ }^{13}$ Alongside this realistic explanation, one may also take into account the farcical nature of the comic stage, which also prevents the Syracusan twin from realizing that people are mistaking him for his brother. ${ }^{14}$ The cook tries to jog Menaechmus II's memory by giving of other plots composed in extra-dramatic space and time: his brother's affair with the courtesan (300) and the liberal supping of wine at her table (302). But Menaechmus II once again denies involvement in these revelries, defending his identity as a newcomer in town and accordingly in the plot (305-6): qui ante hunc diem / Epidamnum numquam vidi nec veni? ('I've never seen or set foot in Epidamnus before this day'). The fact that the cook shows the Syracusan twin the basket of provisions for the meal makes it clear that he still views the twin from Syracuse as composer of the evening's entertainment. Without inviting the 'inset poet' inside Cylindrus enters the house to solicit the courtesan's aid and accordingly lend new impetus to the plot. 
15 As she exits the house, the meretrix orders her servants to ready everything inside (351-6):

ERO sine fores sic, abi, nolo operiri.

intus para, cura, vide, quod opust fiat:

sternite lectos, incendite odoros; munditia

illecebra animo est amantium.

amanti amoenitas malo est, nobis lucro est.

ERO Leave the door like this, go away, I don't want it to be closed.

Get ready inside, take care, and make sure that what's needed is done.

Lay out the couches, burn the incense. Elegance

is an enticement for lovers' hearts.

For a lover loveliness leads to loss, for us, to profit.

16 Here Erotium's instructions are stage directions for the arrangement of the interior 'stage' where the entertainment is to take place. The decision to keep the door ajar is aimed at enticing her guest inside. Her orders admirably bring to the fore the distinct interests of the participants in the festivities; ${ }^{15}$ the emphasis is on perfumes as allurements for lovers, who are a source of revenue for courtesans. ${ }^{16}$ The distinct motives of the two parties are evident in Erotium's mercenary approach and the naiveté of Menaechmus I, who foolishly believes that his mistress is in love with him.

The binary opposition of Menaechmus II as traveler vs. insert poet, elaborated above, is observed again in the encounter between the courtesan and the cook; ${ }^{17}$ any repetition however serves to underline the courtesan's success in coaxing Menaechmus II to take on in his new persona of inset poet for the performance of the feast, as opposed to the cook's failure to do so.

Erotium takes the traveling twin to be the inset poet and wonders why he does not come into the house and therefore the world of the meta-play, further informing him that all his meta-dramatic orders have been acted out. As in the previous scene, Menaechmus II defends his identity as ignotus, and therefore as unrelated to the play within the play, denying any knowledge of her (369-70); but the meretrix declares her love for him on account of his generosity (372): benefactis. His continued rejection of the invitation to the lavish banquet forwards the comic plot and motivates the meretrix to ask why he has ordered to arrange the banquet with her and his parasite following the theft of his wife's palla; but the twin from Syracuse confirms his identity as stranger and accordingly as someone unrelated to these endeavors. The Syracusan's response that she is looking for someone else prompts the meretrix to name his father's name. The name she gives seems to assume the function of a comically staple identity token, disclosing familiarity; it thus removes some doubts from Menaechmus II's mind, eventually allowing him to surmise that the woman may know him, even if she is taking him for someone else.

19 Menaechmus II chooses to assume the part of the inset poet, unknowingly taking on the persona of his brother and eventually displacing him from the plot. This of course is only possible thanks to his twin's meta-dramatic propensities. Messenio once more displays an anti-festive attitude, but is silenced by his master, who informs him of the need to obtain hospitium.

20 As a new poet Menaechmus II amends his brother's meta-play, imposing his own rules, and thus shifts the movement of plot towards his own interests: he excludes the parasite from the feast as he knows nothing of him (423-4): neque ego illum maneo nec flocci facio nec, si venerit, / eum volo intro mitti ('No I'm not waiting for him and I don't 
care for him at all, and if he comes, I don't want him to be in'). In place of another his identical twin - he enters the house alone, having previously instructed Messenio to meet him before sunset.

The entertainment is an off-stage scene, but the audience learns about it when Menaechmus II exits the house, wreathed and carrying the gown, to tell of his achievements (473-7): without paying he has enjoyed full hospitium, slept with his hostess and obtained an expensive gown, which he intends to sell for much needed cash.

The Syracusan twin's remarkable skills as actor are to be seen not only in the off-stage action, but also in the events taking place before the audience. ${ }^{18}$ The courtesan's maid comes out of the house with a bracelet - a further token of Menaechmus I's systematic adultery in the play's extra-dramatic events - and asks him to take it to the goldsmith (524-7). Temporarily forgetting the persona of a party-goer, Menaechmus II asks when the maid needs the bracelet back; but he then steps back into the demands of his role and pretends to remember, true to his habit of playing along with others when he has something to gain. ${ }^{19}$ What is more, he engages in improvisation when he perceives a chance to turn hospitium further to his advantage, seeking information about some armlets supposedly given to the meretrix.$^{20}$ However, the maid's response that no other gifts have been given forces him to step back into the requirements of the role assumed. His ensuing assurances to the maid that he will take care of the gown and the bracelet further demonstrate his play-acting, as in truth he intends to sell them for ready cash (549): ut quantum possint quique liceant veneant ('that it'll be sold as quickly and expensively as possible'). The desire to earn profits from this enterprise is yet again seen when the maid, banking on the generosity that is the hallmark of the Epidamnian twin, asks him to buy her earrings; but Menaechmus II only agrees to do so upon receiving the money. As soon as the maid exits, he tosses the flower garland to the left, towards his brother's house, as a means of casting off the persona of partygoer, and heads off in the opposite direction to meet his slave, thereby resuming the role of traveler (555): ${ }^{21}$ ad laevam manum.

As poeta comicus the Syracusan shows his brother up, taking advantage of the situation and enjoying the comic feast staged by the latter at Erotium's house. ${ }^{22}$ By so doing, however, Menaechmus II also unwittingly helps bring to the fore the true colours of his brother's immediate acquaintances and family, eventually effecting the latter's gradual removal from town.

\section{Estrangement from the family and social milieu}

The alienation of Menaechmus I from his familial and social surroundings begins with the parasite breaking off ties with his patron. This development occurs in the encounter between Peniculus and Menaechmus II, once the latter exits the courtesan's house. The exchange is marked, yet again, by the binary opposition between the stranger and the presumed inset poet, as already seen in the previous encounters with Cylindrus and the meretrix. On this occasion Menaechmus II refuses to assume the alternative comic persona, because he has nothing to gain from his interlocutor; the parasite rages at Menaechmus II for not recognizing him and ironically cuts off all ties with his patron. 
Peniculus sees Menaechmus II garlanded and holding the palla and rebukes him for having cheated him out of the meal in which he has a share. Yet the twin from Syracuse defends his identity as ignotus, offering an explanation for why the parasite has been excluded from his meta-play (500-1): non edepol ego te quod sciam umquam ante hunc diem / vidi nec novi ('As far as I know, I've never seen you or got to know you before this day'). Peniculus demands that the 'stranger' admit to stealing his wife's gown, in evidence that he is in fact involved in his meta-play. Menaechmus II's denial (his own meta-play does not involve theft) disappoints Peniculus, who offers an eyewitness account of Menaechmus I putting on the gown, which was an essential component of his staged trickery. When he draws a blank yet again, the parasite shows his true colours as an opportunist, declaring that he will avenge his exclusion from the banquet by telling all to the matrona (518-21). The irony here is that he will thereby unwittingly set in motion a chain of events that will help Menaechmus II sever the remaining ties keeping his twin in town, therefore leading the comedy to its happy end.

The rift in familial relations develops one step further in the encounter between husband and wife. The parasite and the wife see the local twin returning from the forum; they take him to be the same person who enjoyed the feast earlier on. They hide between the two houses that make up part of the stage scenery (570) and try to listen to his monologue on the corrupt institution of clientela (571-601), providing further evidence for the moral disintegration of Epidamnian society: he went to the forum, but ended up defending his disreputable client in court. This prevented him from arriving on time for the comic feast. ${ }^{23}$ However, the two characters eavesdropping only hear the husband's closing reflections on stealing his wife's palla (601).

The ensuing exchange between the couple reveals the wife's mercenary view of marriage (possibly representative of Epidamnian society), her sole aim being to amass and protect material goods. ${ }^{24}$ Aided by the parasite, she attempts to extract a confession from an evasive Menaechmus ${ }^{25}{ }^{25}$ The wife makes it clear that she is aware that the palla has been stolen as a means of seeking confession, but the husband feigns ignorance and resorts to caressing (607). The sorrow felt by the matrona over the loss of her gown (622, tristis admodum) is the polar opposite of the emotions earlier expressed by the meretrix on seeing her client entering her house with the stolen goods (182): anime mi, Menaechme, salve ('My sweetheart, Menaechmus, hello'). Menaechmus I refuses to make amends for his conduct, pretending not to know why his wife is so upset: he asks whether she has been wronged by the servants, and keeps up the charm offensive (626). Quite unlike Erotium, the matrona once again turns down his advances, further bringing to the fore her materialistic concerns. Meanwhile, Peniculus adds to the comedy of errors (631-4): he rebukes his patron for insulting him earlier and, as is evident to the audience, for excluding him from the comic feast. The local twin fails to persuade his audience of what has happened, even though on this occasion he is telling the truth about not having eaten. Unable to obtain a confession, the wife names her husband as the thief (651) and the parasite accuses him of offering the gown to his mistress so as to gain access to his mistress (652). In his precarious situation Menaechmus I implicitly admits to having taken the gown, but pretends only to have given it to the meretrix on loan (657); and the matrona responds with an ultimatum: he will not be allowed back home unless he returns the stolen item (661-2).

The settlement reached between husband and wife offers the former a chance to retrieve the gown and re-enter his house, restoring the status quo ante. Yet this does not 
imply that he will stop seeing his mistress; ${ }^{26}$ rather, it merely serves to expose the wife's materialistic concerns for the one-way traffic of goods ${ }^{27}$ The play's audience is nonetheless well positioned to posit that the husband will be unable to retrieve the garment, which unbeknown to him is now in the possession of another man - his twin - who intends to sell it on as soon as possible for much-needed cash. ${ }^{28}$

The rift in social relations continues even further in the encounter between Menaechmus I and the courtesan. The scene is designed to put the meretrix on a par with the matrona on the basis of their materialistic concerns, rendering the latter an intraextual double of the former. Viewing events from the perspective of Menaechmus II's inset comedy, Erotium surmises that the married twin has returned to her house to spend more time in her company (677), but the Epidamnian corrects her, seeking the return of the gown now that he has been rumbled (678-9). As actress in the Syracusan's inset play, the meretrix points out that she has already given him the palla along with the sprinter (681-2); but Menaechmus I informs her that he has only recently returned from the forum. On a meta-poetic level his response suggests that his inset play has not yet been acted out. The meretrix suspects that her client intends to deceive her with a view to keeping the gown, although he has already enjoyed her services (685-6). ${ }^{29}$ She thus forbids him entrance to her house (688-95).

Menaechmus I's exclusion from Erotium's house repeats the earlier scene in which he was locked out of his own house. The analogy is reinforced when the meretrix ties the offer of her favors to receiving gifts, doubling the matrona, who is interested in the oneway direction of goods as the central plank of her marriage contract. ${ }^{30}$

\section{Menaechmus II's second comedy}

31 Whereas the performances by Menaechmus II help release his brother from the exploitative relationships he is in, they do not substantially improve his status. The twin is stranded in Epidamnus with no place to go: both houses are shut to him. In the subversive world of comedy, however, conditions now arise for his removal from the polis. This change will allow Menaechmus I to be reunited with his identical twin and depart with him to his homeland, lending a truly happy denouement to the play.

The turning point is reached when the matrona exits the house and comes across Menaechmus II. The encounter between them is marked by confusion over Menaechmus II's true identity, as husband versus peregrinus; it thus reproduces the opposition between inset poet and stranger seen earlier when the cook met Menaechmus II. Any repetition, however, serves to underscore the inversion of the earlier scene: whereas the cook tries to invite the wrong inset poet inside for the realization of comic feast, the matrona rebukes her 'husband' for turning her into a sponsor of his revelries. Symmetrical repetition is cardinal to a play focusing on doubles.

33 The wife sees Menaechmus II returning like a victorious general, with the praeda, the token of his brother's meta-poetic initiatives, on his shoulder. She takes him for the husband and rebukes him for daring to appear in front of her (707-9); she further informs him that she would prefer to live as a divorcee (720): viduam esse mavelim. Menaechmus II defends his identity as peregrinus, and therefore as not her husband, simultaneously asserting his identity as a newcomer (723-4): an mos hic ita est / peregrino 
ut advenienti narrent fabulas? ('Or is it custom here to tell gossip to new arrivals from abroad?'). Unconvinced by this response, the wife directly states her intention to get divorce, lending a further development to the ultimatum-theme (725-6); yet again the threat has no impact on her interlocutor as the matrona is not his wife. In an intratextual allusion to her earlier confrontation with Menaechmus I, the matrona still views him as her husband and censors him for stealing her palla and denying the fact (729); but the stranger asserts that another woman has given him the gown to take to the embroiderer (731-3). On a meta-dramatic level this assertion directs attention to the difference between the inset plots devised by the two twins: as we know, the Epidamnian stole the gown whereas the latter has taken it from the meretrix and intends to sell it. His response infuriates the matrona, who sends for her father, in the hope that he will see how badly she has been mistreated and agree to take her home.

The earlier opposition between husband and peregrinus, examined in the encounter between the matrona and the 'husband', reappears in the meeting between the old man, his daughter and the 'husband'. On his arrival, the senex appears determined to dissipate the tension between the couple and thus help his daughter. In the beginning the old man endorses the comic revelries of his son-in-law: he repeats almost verbatim the husband's opening tirade, chastising his daughter for spying on her husband (788-9) ${ }^{31} \mathrm{He}$ further claims that it is quite within his son-in-law's rights to be seeing the courtesan (790), given the fact that he honors his side of the marriage contract by supplying his legal wife with valuables, including jewelry and clothes. Yet the situation changes when the matrona informs her father that her husband has stolen her gown and spinter to buy the favors of the meretrix (803-4). The senex regards this as a financial damage to the oikos (materialistic concerns are brought up once again), and so he turns to Menaechmus II to hear his defense.

In the presence of the senex, the unmarried twin yet again denies stealing the gown (813-14) or ever entering the house, asserting that he is not related to them in any way (815-17). For both parent and daughter, as compellingly argued by Ketterer, "the surrounding objects signify normal life as they are used to it". ${ }^{22}$ Viewing events from this perspective, the old man takes Menaechmus II's claim not to be living in his house as a mark of insanity (819): insanissume; his daughter points out that the accused man's eyes and temples have turned green, which she interprets in a similar way (828-30)..$^{33}$

Menaechmus II perceives that both father and daughter take his angry denial of their claims as an indication that he is deranged (831-2). Having decided that comic playacting is the only logical way of dealing with the paranoia of the Epidamnians, he once again decides adopt the identity they impose on him, unaware that he is assuming the persona of his sibling ${ }^{34}$ but in contrast to his previous performance this time he impersonates a man driven to madness. His aim is to frighten his harassers for showing hostility towards a peregrinus, rather than offering hospitium, and accordingly shift the movement of plot towards his own interests.

The 'husband's' new performance as a madman yet again underscores his inventiveness and versatility as a comic poet who skillfully adapts to changing circumstances. Scholars have discussed the meta-literary character of Menaechmus II's madness, containing allusions to the ritual possession in Euripides' Bacchae and Hercules Furens. ${ }^{35}$ His impersonation starts with yawning, marking the onset of his disease. Fear of the matrona motivates Menaechmus II to feign possession by Bacchus, who has called him to a hunt (835-9). Unlike his daughter, the senex remains calm (840), leading 
Menaechmus II to renew his strategy and feign possession by Apollo, who orders him to burn the woman's eyes with his firebrand (840-1). In an unforeseen twist, the senex decides that he must fetch slaves to tie the possessed man up, introducing a new dimension to the improvised meta-play (845-6). This forces Menaechmus II to redouble violence and invent a new order from Apollo, commanding him to beat the wife with his fists (846-50). The success of this comic ruse (850-2) encourages Menaechmus II to go even further and scare the senex too. This he achieves first by claiming Apollo would have him beat the old man with his cane (855-6), yet in a spirited defense his opponent threatens to retaliate (856-7). Menaechmus II invents a new divine order to cut the old man's entrails and bones to pieces with a double-edged ax (858-9). The new strategy produces results, as the senex admits to being terrified (861): sane ego illum metuo, ut minatur, ne quid male faxit mihi ('I'm horribly afraid, given the nature of his threats, that he could do me some harm'). The despair of the old man increases (868) when Menaechmus II adds a yet another order from Apollo to trample on him with his chariot. As the senex appears in front of him with his stick, Menaechmus II switches tactics and collapses in a fake faint, supposedly because some other divine power is preventing him from executing Apollo's order to attack the old man (870-1) ${ }^{36} \mathrm{His}$ fall to the ground signals the triumph of his inset comedy, as the senex is dumbfounded at the severity of his illness and hastily exits the stage to call a doctor (875): medicum. Although the recourse to an expert may be read as simply a private and familial initiative, the medical professional is perhaps better seen as representing society, responsible as he is for protecting members of the polis from the threat posed by insanity.

\section{Marginalization within the community}

In his first instance of play-acting, Menaechmus II is responsible for exposing the true nature of his brother's immediate associates and distancing him from his family and social milieu. In the second act, he initiates a process that brings to the fore the true self of the Epidamnian's remaining familial and social surroundings. He thus unwittingly effects the still further removal of his twin from society, eventually leading to his marginalization within the polis. Symmetry thus becomes an essential modality of comic representation.

In terms of stage action, the old man's recourse to the doctor repeats the parasite's earlier resort to the matrona calling her into action (518-21). The close association between the two cases is backed up by the fact that both the senex and the parasite take Menaechmus II to be the husband. Of course, there is a difference in the way the two men react: Peniculus engages in a fierce dispute with Menaechmus II, whereas the old man tries to cure his presumed son in law. This difference however is determined by the fact that the parasite is furious over his exclusion from the lavish banquet, while the old man is a witness to the 'husband's' mad act, and has a long-term interest in restoring harmony to his daughter's marriage.

The mockery of medical consultation culminates when instead of examining the patient, the doctor who has been called in asks the old man to diagnose the sickness (889-1). The two men run into Menaechmus I rather than his brother, but take him to be the madman (898).$^{37}$ The encounter between the father-in-law, the doctor and the Epidamnian (V.5) repeats the exchange involving the matrona, the parasite and the 
husband (IV.2). The dialogic interaction of the two scenes is lent further support by the fact that the old man and the doctor hide in exactly the same spot (899-908) where Peniculus and the matrona withdrew earlier to listen to Menaechmus I's monologue upon returning from the forum (571-601).

In his entrance speech husband recalls the ingratitude of both the parasite and the meretrix, which has left him homeless, and bemoans his fate (899-908). The doctor overhears the husband's despair and at the old man's instigation emerges to examine him, provoking an angry reaction (912), which is interpreted as symptomatic of his condition (912-13). ${ }^{38}$ Subsequent questions about wine (915) annoy the 'patient' still further, leading the expert to pronounce that he is on the verge of insanity (916): iam hercle occeptat insanire primulum ('Now he's beginning to go crazy for the first time'). The alarm of the senex explains his ensuing request to the doctor to administer hellebore so as to save his daughter's marriage (919-20); but as a true professional the doctor wishes to complete the medical interview before prescribing any treatment (921): mane modo, etiam percontabor alia ('Just wait, I will ask about other things'). Notwithstanding the difference in motives, in his exhortations the senex here appears as an intratexual double of Peniculus, who in the relevant encounter with the husband and the matrona exhorts the uxor to teach her husband a lesson: 604, 628. The doctor interprets the Epidamnian's curse as the onset of his disease (934): nunc homo insanire occeptat: de illis verbis cave tibi ('Now he's beginning to have a fit. Be careful on account of these words'); but the senex claims this is nothing compared to his earlier outburst, in which he called his wife a bitch and issued death threats (935-6), though ironically this was done by his twin. Mutatis mutandis, the senex yet again appears as an intratextual double of the parasite, who also confused him with his twin in the symmetrical encounter with the matrona, when he chastised his patron for claiming to be an unknown outsider (631-4). The husband's angry response to the nonsensical allegations of his father-in-law prompts the latter to call the doctor for further action since he has been driven insane (946): non vides hominem insanire? ('Can't you see that he's crazy?'). On the basis of social institutions, the doctor has the legal authority and obligation to protect public health. He thus orders that four strong slaves be called to forcibly remove the patient to his psychiatric clinic (953), on the grounds that Menaechmus represents threat to society. This notion is backed up by the fact that the doctor is too afraid to stay alone with his patient and guard him when the old man goes off to fetch the slaves (954-5). ${ }^{39}$

In effecting the marginalization of the married twin from the community, the doctor appears to occupy a similar position to the matrona, who blocks her husband's entrance into his house. Further credence is given to such a view if one considers that the polis constitutes a macrocosm of the oikos. The demotion of the married twin within society, as with his exclusion from home, further reveals the intolerance of the Epidamnians towards the married twin, whom they have always treated as a peregrinus.

\section{Rescue from marginalization}

In the wake of the symposium Messenio enters the stage to accompany his master to the ship. His monologue on the values of being a good and a fearful slave as a way of earning freedom from his master (V.6) offers an explanation for his earlier objections 
to festivities and prefigures his action when he sees the tough slaves beating Menaechmus I and attempting to drag him off to the doctor's clinic (V.7). ${ }^{40}$

The scene involving the new humiliation of the husband (V.7) duplicates the embarrassment he suffered outside the door of Erotium's house (IV.3). The analogy is backed up by the fact that the second incident (V.7) occurs hard on the heels of his encounter with old man and the doctor (V.5), just as the first followed on from the exchange with his wife and the parasite (IV.2). Any duplication should direct attention to the failure of the slaves to achieve their aim, which is entirely due to Messenio's presence at the events (V.7), unlike the husband's earlier embarrassment outside Erotium's doors, where he was all alone on stage (IV.3).

The slave sees Menaechmus I being beaten up by the slaves, takes him for his master and rushes to his aid. What is worth observing here is that in his engagement with Menaechmus I Messenio is not at all offended at not being recognized by his 'master'; and this is in opposition to all other characters in the city, who are insulted at not being recognized by Menaechmus II. $^{41}$ The absence of any offence on the part of Messenio eliminates the tension observed in all previous encounters between Menaechmus II and the Epidamnians and explains the positive evolution of plot: he beats off the harassers and rescues Menaechmus I from incarceration in the clinic, preventing his 'master' from being totally estranged from the polis.

Messenio's ensuing request that he be liberated in reward for his services (1023), already foreshadowed in his monologue (V.6), is answered by the Epidamnian claiming that he is not aware any of his own slaves having offered him such assistance (1027): nec meus servos umquam tale fecit quale tu mihi ('My slave has never done anything of the sort you did for me'). Messenio lends a literal meaning to the Epidamnian's response and stages his manumission (1031-4), ${ }^{42}$ though the liberation is a false one, ${ }^{43}$ in alignment with the 'true and false' theme running through the play.

Menaechmus I's total bewilderment is seen when he sums up all the misadventures that have befallen him to that day (1039-47), entirely unaware that they have been triggered by his twin's presence in the action..$^{44}$ In his confusion he makes one last-ditch attempt to regain the gown from the meretrix, hoping that he will be allowed to return to home and ironically restore the status quo ante (1048-9). Yet the counter directional movement towards liberation begins with the local twin's alienation from his family and social milieu and is then secured with Messenio's timely intervention, eventually preventing Menaechmus I's incarceration in the clinic. This allows for the truly happy plot twist whereby the brothers recognize each other and all earlier plot complications are resolved.

This development occurs when Messenio sees the Epidamnian yelling outside Erotium's house that they did not give him the gown and bracelet that day, as his own revelries within the play never took place, and observes his likeness to his master. The fact that both brothers lay claim to the same name, the same place of origin and the same father, a fact which initially puzzles the slave, eventually allows him to surmise that this man must be the long lost brother they are searching for, and to inform his master in private of this intuition. ${ }^{45}$ Messenio obtains a promise to gain his freedom should he discover the twin (1093-4): liber esto, si invenis / hunc meum fratrem esse ('You shall be free if you find out that he's my brother'). 

then his alleged son-in-law, Messenio conducts the percontatio and demonstrates beyond any doubt that Menaechmus I is indeed his master's lost brother. What is more, the slave also disentangles all the plot complications with Erotium arising from errors over the two adulescentes of identical appearance. His unraveling of all misunderstanding has a meta-poetic color, helping define the play as 'comedy of errors' (1135-6). The two protagonists then confirm Messenio's 'literary evaluation' of the play, filling in the pieces of the plot the other twin is ignorant of (1137-45). has assisted in the evolution of plot towards the recognitio of the brothers and brought about the lasting happiness of his master, who longed to be reunited with his lost twin. At the outset of play Messenio plays a blocking comic character, whereas in this scene he is clearly a plot mover, in the sense that he helps with the eventual saving of Menaechmus I from estrangement. This will ultimately lead to comic recognition.

51 Following the reunion, Menaechmus II proposes that his brother return with him to their homeland. The cutting off of all ties to Epidamnus takes the form of an auction at the play's end, in which Menaechmus I intends to sell off everything he has acquired; ${ }^{46}$ the surprising appearance of the wife among the items put on sale is certainly a joke (1160), but also seems to have been designed to fit into the broader context of Menaechmus I's gradual alienation from town.

With his decision to return to his native land the local twin makes it clear that he has finally perceived the true character of the Epidamnians, and further discloses his failure to integrate into their society on account of his differences from them. What is more, the decision serves as evidence of the intolerance that the locals showed towards the married twin, treating him as an alien and eventually attempting to remove him from the polis via isolation in the clinic.

\section{Conclusion}

On the basis of the above discussion, it can be concluded that Menaechmus I, who has been abducted at a young age and is living in Epidamnus, is exploited by his family and social milieu without perceiving it. Unbeknown to all, the arrival of his twin brother initiates a change both in the plot direction and in his fortunes, leading to his removal from town. This is enabled when Menaechmus II unintentionally intervenes as the composer of two inset performances, both of which hinge on the meta-dramatic propensities of his twin. The two acts of impersonation mirror one another, reinforcing the unity of the play's plot: in the first Menaechmus II brings about the distancing of his twin from his household and social surroundings; and in the second he prompts further ostracism within the town through the incident involving the doctor. Symmetrical doubling and replication confirm the main axis around which the play revolves. The Epidamnian's rescue from marginalization following the second inset play is entirely due to Messenio, who arrives on time and frees him from his harassers. This leaves open the prospect of the twins being blissfully reunited, and eventually returning to their native Syracuse. Thus Menaechmus II's quest for his identical twin, which seems to have been deferred upon his arrival in town, has effectively been carried out through the fruition of his meta-plots. 


\section{BIBLIOGRAPHY}

Bernstein, Neil W (2017), Seneca: Hercules Furens, Companion to Greek and Roman Tragedy, London. Braund Morton, Susanna (2005), "Marriage, Adultery, and Divorce in Roman Comic Drama", in Warrens S. Smith (ed.), Satiric Advice on Women and Marriage: From Plautus to Chaucer, Ann Arbor, 39-70.

Bungard, Christopher William (2008), Playing with Your Role in Plautine Theater, PhD Diss., Ohio State University, Columbus.

de Melo, Wolfgang (trans.) (2011), Plautus: Casina; The Casket Comedy; Curculio; Epidicus; The Two Menaechmuses. Loeb classical library, 61. Cambridge, MA; London.

Duckworth, George (1971), The Nature of Roman Comedy: A Study in Popular Entertainment. Princeton. Dutsch, Dorota (2008), Feminine Discourse in Roman Comedy. On Echoes and Voices. Oxford.

Fantham, Elaine (2010), Roman Readings: Roman Response to Greek Literature from Plautus to Statius and Quintilian, Berlin, 1-31.

Frangoulidis, Stavros (2017), “Aphrodisia and the Poenulus of Plautus: The Case of Agorastocles", in Stavros Frangoulidis and Stephen Harrison (eds.), Life, Love and Death in Latin Poetry: Studies in Honor of Theodore D. Papanghelis, Berlin, 207-19.

Gratwick, A.S. (ed., comm.) (1993), Plautus, Menaechmi, Cambridge.

Gruen, E.S. (1990), Studies in Greek Culture and Roman Policy, Berkeley.

Ketterer, Robert (1986), “Stage Properties in Plautine Comedy III: Props in Four Plays of Identity”, Semiotica 60, 29-72.

Konstan David (1999), Friendship in the Classical World, Cambridge.

Leach Winson Eleanor (1969), "Meam formam noscito: Language and Characterization in the Menaechmi”, Arethousa 2, 30-45.

Marsilio, M.S. (1998), “Two ‘Ships' in the Menaechmi”, CW 92, 131-59.

McCarthy, K. (2000), Slaves, Masters, and the Art of Authority in Plautine Comedy, Princeton.

Maurice, L. (2005), “A Calculated Comedy of Errors: The Structure of Plautus' Menaechmi”, Syllclass 16, 31-59.

Moore, T.J. (2001), The Theater of Plautus: Playing to the Audience, Austin.

Muecke, Francis (1987), Plautus Menaechmi: A Companion to The Brothers of Menaechmus, from Plautus, Bristol.

Murray, S.A. (2007), Quis ego sum saltem? An Investigation of Plautus' Captivi, Menaechmi, Amphitruo with Special Reference to Problems of Identity, PhD Diss. KwaZulu-Natal, Durban.

Rouse, W.H.D. (ed.) (1912), The Menaechmi: The Original of Shakespeare's Comedy of Errors, London.

Rosivach Vincent J. (2002), When a Young Man Falls in Love: The Sexual Exploitation of Women in New Comedy, London.

Schiesaro, Alessandro (2003), The Passions in Play. Thyestes and the Dynamics of Senecan Drama, Cambridge. 
Segal, E. (1968), Roman Laughter: The Comedy of Plautus, Cambridge MA

(1969), “The Menaechmi: Roman Comedy of Errors", Yale Classical Studies 21, 77-93.

Sharrock, Alison (2009), Reading Roman Comedy, Cambridge.

Slater, N.W. (2000), Plautus in Performance, Amsterdam.

Steward, Roberta (2012), Plautus and Roman Slavery, Malden MA and Oxford.

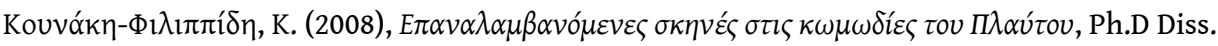

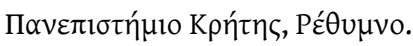

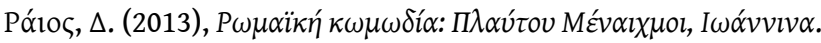

\section{NOTES}

1. Leach 1969, 36 points out that Menaechmus of Epidamnus is doubly bound: to his wife and to his mistress Erotium. Also Segal 1987, 43, points out that "The Epidamnian twin is bound by innumerable ties, legal, financial, and social obligations, not to mention his marital bond to a shrewish wife who is constantly 'on the job"'.

2. E.g. Maurice 2005, 50-54, comments on Menaechmus of Syracuse's successful playacting and guile, particularly when compared to the failure of his twin to show cunning in his various pretenses within the play; Fantham 2010, 18-26; MaCarthy 2000, 54, 58.

3. On Plautine metatheater and the role of servus fallax see the excellent discussion in Slater 2000. My understanding of metatheater also takes into account the role of characters acting as prime movers attempting to gain control of plot, as admirably illuminated by Schiesaro 2003, passim, in his seminal study on Senecan drama.

4. I owe this comment to David Konstan, per litteras.

5. See Sharrock 2009, 45.

6. Gruen $1990,127$.

7. Muecke 1987, 30. On the matrona as slightly different from a typical uxor dotata, "for being young and seen in relation to a father as well to a husband", see Sharrock 2009, 45.

8. On scheming slaves as poets in Plautine comedy, see Slater 2000.

9. Segal 1987, 44. On military imagery see Leach 1969, 34-5; also Ketterer 1986, 53. McCarthy 2000, 43 suggests that the way in which the Epidamnian exults over his wife in military terms creates an association with the trickster slaves of comedy.

10. Segal 1987, 47-8.

11. Gruen 1990, 127, Duckworth 1971, 77.

12. Muecke 1987, 39. For parallels of freeborn individuals sold into slavery see Plautus' Captivi, where all freeborn characters become slaves as a result of war or kidnapping.

13. Ketterer 1986, 55.

14. I would like to thank the anonymous reader for this idea.

15. Bungart 2008, 99-100.

16. Bungart 2008, 99-100 contrasts Erotium's attitude with the sentimental attachment of Philocomasium.

17. Muecke 1987, 44. For an exemplary study of Plautine plays from the perspective of symmetries and mirror scenes see Philippides 2008, 41-6, with limited discussion of Menaechmi.

18. Maurice 2005, 51.

19. Maurice 2005, 51.

20. Maurice 2005, 52.

21. Ketterer 1986, 57. 
22. Segal 1987, 50, points out that his local twin suffers "a double damnum, physical as well as fiscal".

23. Segal 1987, 50.

24. McCarthy 2000,56 .

25. McCarthy 2000, 56.

26. Ketterer 1986, 59.

27. Ketterer 1986, 58

28. Much to Peniculus's disappointment, it rapidly emerges that the matrona has absolutely no intention of filling his belly in recompense for services rendered (664). His inability to secure an invitation from the wife replicates his earlier exclusion from the feast with Erotium. As a result, the parasite cuts off all ties with the oikos and leaves the stage for the last time (666): cum viro cum uxore, di vos perdant! ('Both husband and wife, may the gods ruin you!'). Despite the curse, the severing of this association can only do Menaechmus good.

29. On the contrast with Erotium's earlier blanditia, upon receiving the dress, see Dutsch 2008,16 and 58-9.

30. Ketterer 1986, 53.

31. Segal 1987, 46.

32. Ketterer 1986, 59.

33. On the wife's description of Sosicle's feigned symptoms to her father as playing with the conventions of Euripides' Hercules Furens see Bernstein 2017, 51-2.

34. Maurice 2005, 52.

35. For the presence of language both from Euripides' Bacchae and Heracles see Leach 1969, 39-4; on para-tragedy see detailed discussion in Fantham 2010, 19-21.

36. Sosicles' collapse further recalls the Euripidean Heracles who falls into a comma, following his onset of madness.

37. On this symmetry see Philippides 2008, 44-5.

38. Muecke 1987, 65.

39. Muecke 1987, 66.

40. Muecke 1987, 66.

41. Marray 2007, 106.

42. For Messenio's invitation to the spectators as participants and witnesses in his manumission see: Stewart 2012, 152; and Moore 1998, 42-3.

43. Muecke 1987, 68.

44. See also Muecke 1987, 69.

45. Murray 2007, 100.

46. Ketterer 1986, 61; see also Braund 2005, 55-8.

\section{ABSTRACTS}

This paper explores how Menaechmus II of Syracuse unintentionally succeeds in removing Menaechmus I, his Epidamnian twin, from a society which has been exploiting him. The process of withdrawal runs through the play, and is achieved in two stages in which Menaechmus II assumes his twin brother's meta-dramatic role: in the first play the newly arrived brother alienates the Epidamnian twin from his immediate social and family milieu; and in the second he 
almost leads the Epidamnians to have his brother isolated within the community on account of the latter's alleged insanity. As servus bonus, Messenio initially discourages Menaechmus II from comic merrymaking, thus impeding the reunion of the siblings, but later assists in forwarding the plot: he thwarts the Epidmanians' intention to seclude him and eventually facilitates the recognitio between the twins as well as their final decision to return to their native land. Thus, Menaechmus II's quest for his twin, which seems to have been deferred when he first arrives in Epidamnus, is prepared for and effectively carried through via the evolution of meta-plots.

\section{INDEX}

Mots-clés: Plautus, Menaechmi, poeta comicus, estrangement, marginalization, recognitio, reunion 